\title{
Developing Picture Describe For Elementary School Students' Speaking Skills
}

\author{
Abdullah Farih, Afifa Eka Kurniawati Dewi
}

Universitas Islam Lamongan

\begin{tabular}{l} 
INFO ARTIKEL \\
\hline Riwayat Artikel: \\
Diterima: 07-02-2021 \\
Disetujui: 21-02-2021 \\
\hline
\end{tabular}

\section{Kata kunci:}

Speaking Skills

Describing Picture

Elementary school

\section{Alamat Korespondensi:}

Abdullah Farih

Universitas Islam Lamongan

Jetis, Kec. Lamongan, Kabupaten Lamongan, Jawa Timur

E-mail: abdullahfarih@unisla.ac.id, Afifaekakurniawatidewi@gmail.com

\begin{abstract}
The main purpose of this study is to help the English teachers easily to teach speaking in teaching English by describing picture. The activities are consists of reading, listening and talking. The researcher employed Research and Development method (R\&D) and adapted Borg and Galls' model which consisted of five stages, namely 1) research and information collection, 2) planning, 3) develop preliminary form of product, 4) preliminary field of testing, and 5) main product revision. The researcher used three instruments to obtain the data such as interview, questionnaires and observation checklist. The obtained data will be classified based on the instrument used. The researcher shows the result by explaining them in quantitative and qualitative approach. The students needed supporting book in learning English that has attractive and colourful picture for students. The product is a describing picture book for elementary school entitled PICRIBE. The result of expert validation of the book is percentage of $4,0 \%$ and $4,5 \%$ is the result of expert validation ofthe materials. It means the bookis feasible as supporting media in learning speaking.
\end{abstract}

Abstrak: Tujuan utama dari penelitian ini adalah untuk membantu para guru bahasa Inggris dengan mudah dalam mengajar berbicara dalam pengajaran bahasa Inggris dengan mendeskripsikan gambar. Kegiatannya terdiri dari membaca, mendengarkan dan berbicara. Peneliti menggunakan metode Research and Development (R\&D) dan mengadaptasi model Borg and Galls yang terdiri dari lima tahap, yaitu 1) penelitian dan pengumpulan informasi, 2) perencanaan, 3) pengembangan bentuk awal produk, 4) pengujian lapangan awal, dan 5) revisi produk utama. Peneliti menggunakan tiga instrumen untuk memperoleh data yaitu wawancara, kuesioner dan lembar observasi. Data yang diperoleh akan diklasifikasikan berdasarkan instrumen yang digunakan. Peneliti menunjukkan hasil dengan menjelaskannya secara kuantitatif dan kualitatif. Siswa membutuhkan buku pendukung dalam pembelajaran bahasa Inggris yang memiliki gambar menarik dan berwarna bagi siswa. Produk berupa buku bergambar deskripsi untuk sekolah dasar berjudul PICRIBE. Hasil validasi ahli buku prosentase $4,0 \%$ dan $4,5 \%$ hasil validasi ahli materi. Artinya, buku layak sebagai media pendukung dalam pembelajaran berbicara.

\section{INTRODUCTION}

Education has become a priority because it involves most people to take part in this matter. Education is a bridge that will lead people to a better future. Education performs the main role in the country development. The development can be determined by whether its citizens have a good education or not. 
The world of education in the era is needed to prepare students who can show their superiority, it is intelligence, personality, and spiritual character. According to (Indonesia, 2003) on National Education System; Education is conscious and well-planned effort in involving learning environment and learning process in order who learners are going to be ready to improve their potential in the acquiring spiritual and non-secular strengths, selfcontrol developing, personality, intelligence, morals, and good character and skills which needs for him/herself, for the community, for the nation, and the State.

In Indonesia, the government is very concerned about education by constructing several adjustments, specifically for primary and secondary level. Education of Indonesia is started from kindergartens to universities. Curriculum is a plan for education in Indonesia to achieve goals. According to (Fatmawati, 2009), the curriculum is an educational program that states three things, namely: 1) the educational objectives of a program, 2) the content, teaching procedures and learning experience needed to achieve these goals, and 3) tools to measure whether these goals have been achieved or not.

The English subject is based on the 1994 curriculum for elementary schools. Specifically, the program on including English language subject in primary schools is according to the policy of the Indonesian Ministry of Education and Culture No. 0487/1992, Chapter VIII states that curriculum in the primary level can be added. The most important thing in the education is teaching language, because the best way to communicate is language. "Language is a purely human and non-instinctive method of communicating ideas, emotions unit desires by means of voluntarily produced symbols" (Bashir et al., 2011). Four language skills; speaking, listening, reading, and writing; acquired in different stages in the developmental phase of a student's language. Learning a second or foreign language means learning to communicate. Second language learning calls the process of developing ability in another language. In Speaking, communication involves interaction with one or more people. Effective communication also includes good hearing, an understanding how the other feels. (Harmer, 2007), states there are several elements in speaking. They are language features, language management and interactions from others.

Speaking is the way to communicate, so learning English speaking very important. "The most people, mastering speaking are the most important aspect of learning a second language" stated (Nunan, 1991). Speaking is the first step to know someone language ability. Speaking looks intuitively the most important language skill, and people who know a language are referred to as 'speakers' of that language, as if speaking included all other kinds of knowing, and many if not most foreign language learners are primarily interested in learning to speak. In addition, success in learning a language is measured in terms of the ability to carry out a conversation within the target language (Nunan, 1991). Speaking has an important role in carrying out social interactions with others. Therefore, everyone needs to master speaking skills. Speaking is a way to express opinions, feelings, experiences, and knowledge to others in formal situation or in the informal situations. Lack of speaking skills can cause people to do not be successful in their school or community.

Some students find problem in learning speaking. The problem comes from the students; they are difficult to use the foreign language, lack of motivation to practice the second language, especially English in the dialog. Studying second language, the key factor to improve proficiency is motivation. It is known by two important elements: learners' demand for communication and their attitudes towards the foreign language (Al-Sobhi \& Preece, 2018). Learners are also very shy and afraid to take part in the dialog. Some of the factors are comes from material, media and teaching technique. In teaching English is the first can be motivated the students to study English and many techniques can be applied to teach them including describing pictures.

Pictures are good visual tools in process of learning in the classroom. As cited in (Pratiwi \& Ayu, 2020)" Picture, one of the visual aids, is every type of pictorial presentation", and according to (Ratminingsih \& Budasi, 2018)," pictures media can support the teacher to involve the student's interest and enjoy learning English. Pictures also represent the real situation”. From statements above, the researcher used picture as a media to teach speaking, bringing the real situation to the classroom. Based on the researcher's observations in SDN Kebalandono, the researcher presents the students' difficulties in English speaking lessons. From lack of vocabulary and arrange to be sentences until difficult to pronounce. They only have an English book from the school. They need some references book. The researcher tries to apply "PICRIBE" in speaking skills. The media to teach is used as a picture describing book. The researcher chooses a book to develop speaking skills that will be given to help the students.

From the discussion above, the researcher chooses "Developing "PICRIBE" in Students' Speaking Skills for the Fourth-Class of Primary School" The study helps to methodologies and strategies oriented to the development of Picture Describe for the learners to make a good in English speaking skills. From the discussion above, the researcher involves the student in answering the research problem which contains how "PICRIBE" develops the 
students' speaking skills in elementary school. The study will help to methodologies and strategies oriented to the development of Picture Describe for the learners to make a good in English speaking skills.

\section{Speaking Skills}

Teaching learning process in English speaking skill requires the ability to master some components of the language of vocabulary, the composition of the sentence and the way of pronunciation. According to Keith and Morrow as cited in (Inayah, 2019) speaking skill is an activity by saying sentences made by two or several people acting as speakers and listeners in order that they will react consistent with what they mean. (Tarigan, 2006) adds that speaking skill is the skill of conveying messages through spoken language. The link between spoken language and message as medium of delivery is very heavy. The message received by the listener is in the form of a language sound rather than in another form. Then the listener diverts the message in the form of the language sound into what the speaker is saying.

About speaking skill, Tarigan says that there are several general goals in conducting speaking classes. They are; 1) entertaining, the speaker attracts the attention of the listener by means, such as humour, spontaneous excitement, funny stories, adventures and so on to create an atmosphere of excitement for the listener, 2) informing, this purpose is implemented to explain a process, to describe, to translate, or to interpret something, to give, to spread or to provide knowledge, 3) stimulating speech, according to Tarigan, speaking must be smart to persuade, to influence, or to convince listeners. This can be achieved if the speaker knows the listener's willingness, interests, inspiration, needs, and aspirations.

\section{Speaking for Young Learner}

Young learners are elementary school students aged 6 to 12 years. It can be grouped into two groups, namely younger (6 to 8 years) and older (9 to 12 years) group. According to (Cooper, 2007), young learners are in group level one (5 to 7 years) or level two (8 to 10 years). These are brief discussion of characteristics of young learners adopted from (Cooper, 2007). Young learner refers to the elementary school students (6 to 13 years). They have certain characteristics, namely as follows:

1. They have a first language, and they can read and write already.

2. These student's capability can facilitate their learning.

3. They like activities or movements.

4. Students at this age cannot just sit and silent still for a long time. They like moving.

5. They have limit time to concentrate. They bored easily.

6. So, the English lesson should be in short time.

7. They like asking.

8. The teacher should patiently answer their questions and include them as the teaching and learning activities.

9. They have some world knowledge.

10. These students are not "blank slate" and possibly, unconsciously, they have mastered some English words.

11. They can work in groups.

12. This will give the possibility of conducting group works.

13. They are naturally ready to learn a foreign language.

Motivating to find out the target language should be given to the students. The task of the teacher is to maintain and to grow the motivation. Characteristics of young learners are 1) having a self-pride attitude, 2) difficult to distinguish concrete things and abstract things, 3) tending to be imaginative and active, 4) have a feeling of being easily bored, and 5) children's lives are colourful and cheerful (Cooper, 2007). Speaking skills as a young English learner is very important. Children like to talk, therefore young learners in elementary schools need to be more focused on speaking skills. Some activities that can make students active and willing to talk include 1) simple dialogue, 2) classroom language, 3) role play and situational dialogue, 4) talking about something, and 5) describing a picture. (Kusumawardhani \& Nurhayati, 2019) as quoted by (Inayah, 2019) states that some factors that make difficulties English Young Learner (EYL) speaking are associated with the learners themselves, the teaching strategies, the curriculum, and therefore the environment. So, the teacher should understand some of the factors involve the students in learning English for young learners. Some students also lack speaking English motivation. 
They do not really want to speak and learning English. The speaking skills development can only happen if teacher give them motivation and students' identity and people around give opportunity to precise them.

\section{Curriculum of Elementary School}

English subjects can be officially taught in elementary schools since the 1994 school year as local content subjects. Officially the policy on including English language subject in primary schools is following the policy of the Indonesian Ministry of Education and Culture No. 0487/1992, Chapter VIII, which states that primary schools can add subjects to their curriculum, provided the lessons do not conflict with the aims of national education. Then, this policy was followed by Decree of the Minister of Education and Culture No. 060 / U / 1993 dated 25 February 1993 concerning the possibility of an English language program as a subject for local elementary content and can be started in 4th grade elementary school. Schools have the authority regarding English subjects included as one of the local contents taught in primary schools based on situation, condition, and consideration of both parents and the community. This policy has a positive impact program to the community and the schools. Over the few years, there has been an increasing tendency for schools to implement English language teaching programs starting from elementary schools.

\section{Picture for Young Learner}

Media is the tool, material, or an event that is used to support the instruction to achieve knowledge, skills, and attitudes. Gerlach and Elly as cited in (Harjuno, 2009) propose, "A medium is any person, material, or event that establishes conditions, which enable learners or students to acquire knowledge, skills, and attitudes." Meanwhile, (Brown, 2007), determines media because the items or the things physically employed by an educator to the instruction facilitate. Pictures are often in sort of flashcard, cue cards, pictures of large wall, illustration or photographs, and projected slide. It means by using picture, the scholars can bring the real situation to the classroom. Picture is the visual aid that is used to help and support a teacher to the students' attention. (Piaget, 1976) in cognitive development theory stated that, pupils are within the sensor motor phase. Pupil achieves knowledge from their senses and that they wish to look something visual during this phase. So, teaching and learning process more interesting and enjoyable when using picture.

(Harmer, 2007), states that a range of objects, pictures and other things can be used as instructional media to present and manipulate language and to involve students in the activities. (Campbell \& Wright, 1990), says that picture is not just an aspect of method but through its representation of place, object, and people, it is essential part of the overall experiences. Pictures are considered more effective because they can make students able to catch the idea clearly. (Van Kraayenoord \& Paris, 1996) adds the five primary reasons of using picture: it is easy to prepare, to organize, interesting, meaningful, and authentic. A lot of research has been done related to teaching learners using pictures, whether they were young learners or adults. Most of the result showed positive sides of using pictures as teaching media.

\section{"Picribe" Book}

Pricribe is a book containing English material for fourth-grade children in primary school. The objective of this book is to develop material in speaking skills. The book contains of picture describing that related to the learners' speaking skills. The learning material of each unit is put together according to a particular theme. The themes chosen are based on the elementary school curriculum. Researchers are aware of the tendency of elementary schools still using books as a medium for teaching materials so that researchers use book media as a supplement to improve speaking skills in the fourth grade of elementary schools. Learning resources are all sources used to gain knowledge, can be in the form of tools such as textbooks, etc. AECT (Association for Educational Communication and Technology) classifies components of learning resources in educational technology in messages, people, materials, tools, procedures, and the environment. Referring to learning resources in AECT, the tools referred as learning resources can be in the form of absolute facilities and infrastructure, such as curriculum, textbooks, stationery, learning places, etc.

Describing picture functions are to practice describing things and using position preposition, to listening practice and chatting with direction, to coach students, retell story and imagination in English speaking skill. The gain of using PICRIBE is alright for beginner and for young learner. Many gaining describing picture are: 1) more interactive learning, 2) reducing time required, 3) more interesting instruction, 4) improving the quality of learning, 5) students' positive attitude can be enhanced. Picture describing is a method that easy to play. It is very good 
method to the elementary School students. The students more maximum used their five senses, saw the picture by suing eyes, listened partner speaking by using ears, describing picture by using mouth. So that, students' more active by using describing picture.

\section{METHODS}

This research aims to develop speaking material based on describing pictures for elementary school students at SDN Kebalandono Lamongan. The main purpose of this research is to help English teachers teach speaking easily by using picture descriptions on students. The subjects in this study were grade 4 students at SDN Kebalandono. This research was conducted using research and development (R\&D) research design. According to (Gunasekaran, 1999), research and development methods are research methods used to produce certain products and test the effectiveness of these products. In the world of education, research and development is research used to validate and develop product of education (Gall et al., 1996).

There are many types of design models developed by experts, but the researcher chooses a design model developed from (Gall et al., 1996; Hamzah, 2019), which consists of ten steps which is a popular model used in research development in the department of education. The procedural steps in developing the teaching materials by Borg and Gall are: 1) research and information collection, 2) planning, 3) develop preliminary form of product, 4) preliminary field testing, 5) main product revision, 6) main field testing, 7) operational product revision, 8) operational field testing, 9) final product revision, 10) dissemination and implementation. The researcher simplifies the stage in accordance with the place, purpose, complication, and time of the research. From ten stages, the researcher used five steps.

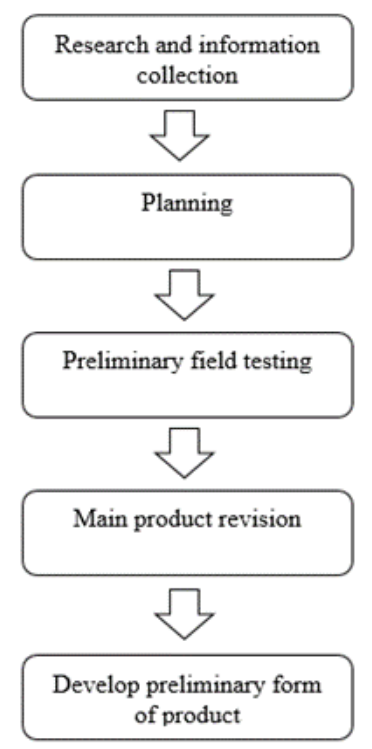

Fig 1. Researcher steps

\section{Population and Sampling}

\section{Population}

Population is point of all elements possessing one or more attributes of interest. In other words, we can mention that a population is the whole research subject. (Gunasekaran, 1999; Karimata, 2019) stated, "The population means generalization region consists of; objects / subjects that have certain qualities and characteristics are determined by investigators to be studied and then drawn conclusions." The population is whole subject of research. The population of this study is fourth grade students of SDN Kebalandono in the academic years 2019/2020. This study is implemented in second semester. The total population was 14 students. The researcher overcomes the problems related to speaking skills on their learning. The researcher in is identifying the problem of the process of English teaching learning related to the teaching English to the students. 


\section{Sample}

Sample is part of population taking using certain procedure so that it can be expected to represent its population. The researcher uses 14 students who have different English skills.

\section{Data Collection and Techniques}

The data procedure of data collection is as the followings:

\section{Interviewing}

For the first interviewing, the researcher does to the teacher and collects information in the research setting. The collected information is used to know the real problem in the field, for example to know whether material used is suitable for students or not. The second interviewing has purpose to know the developed speaking itself, whether the speaking skills using PICRIBE is effective or not.

\section{Observation}

The observation is to get the fact the classroom learning process, the researcher uses field-note taking in collecting the data. It is important information as principle in the developing speaking.

\section{Questionnaire}

Questionnaire is data collection technique by giving a set of question to the respondent to answer. It was created to know some suggestion and revision that should be made by the researcher. Furthermore, it was done to help the researcher know about the product weakness.

\section{Data Analysis Technique}

Based on the data collection technique, it is divided into two approaches: quantitative and qualitative. The quantitative approach can be done by giving questionnaire while the qualitative approach can be done by observation and interview.

\section{Observation and Interview}

The observation and interview data are interpreted descriptively. The researcher presents at the action scene but does not interact or participate. The researcher sees sheet which includes the activity, actor, and place. The description forms as represent the result.

\section{Questionnaire Analysis}

The researcher makes two steps questionnaire, which is research and collecting data and preliminary field testing. Likert scale is used to measurement of the questionnaire. "Skala bertingkat, yaitu jawaban responden dilengkapi dengan pernyataan bertingkat, biasanya menunjukkan skala sikap yang mencakup rentang dari sangat setuju sampai sangat tidak setuju terhadap pernyataannya, (Hamzah, 2019). The data are analyzed using the following formula adapted from Likert scale, as in Figure.

$$
\text { Percentage } 100 \% \frac{f x 100 \%}{N}
$$

$\begin{array}{ll}\mathrm{f} & : \text { Frequency } \\ \mathrm{N} & \text { : the number of students } \\ 100 & \text { : fixed number }\end{array}$

The data from the expert validation then are calculated in different formula. The formula used as in Figure 3.4 whichis purposed by Levin and Stephen (2010:63).

$$
\text { Percentage } 100 \% \frac{f x 100 \%}{N}
$$

Xi : The sum of data values

$\mathrm{N} \quad$ : The number of summed data

To interpret whether the development materials are acceptable and good, the researcher shows the assessment of the mean. The assessment of the mean is discovered in Table 1. 
Table 1. The assessment of the mean

\begin{tabular}{ccc}
\hline Scale & Range & Categories \\
\hline 1 & $0-1$ & Very Poor \\
2 & $1.1-2$ & Poor \\
3 & $2.1-3$ & Fair \\
4 & $3.1-4$ & Good \\
5 & $4.1-5$ & Excellent \\
\hline
\end{tabular}

\section{RESULTS AND DISCUSSION}

The research was conducted in February until April 2020. The findings cover the results of research and information collections, planning, develop basic product form, testing previous product revision and final product. Research and development conducted by researcher using the Borg and Gall development procedures.

\section{The Result of Research and Information Collection}

The research and information collection conducted in February 2020, at SDN Kebalandono. There were three kinds of instruments used to conduct the research and information collection. They are questionnaires, interview guidelines and observation checklist. The first instrument was questionnaires distributed to the students of fourth grade. The second instrument was interview guidelines given to the students and teachers of SDN Kebalandono. Then, the researcher used observation checklist as the last instrument when reaching the try out stage. From the collecting data information, the researcher found that the students needed media in learning English. The media that used was book. The students assumed that describing picture can help them to learn speaking. So, the researcher developed picture describe as a media to teach them.

\section{Planning}

The steps were taken by researcher in planning product development, including determining the learning objectives, determining the appropriate module titles and creative, selecting materials, preparing a framework in which there are materials, teaching sequence, and material collection. It was explained: a) The formulation of objectives was made known to students as the results they achieved after using books. Thus, students were found out what they can after learning to use this book, especially in speaking learning, b) the selection of materials used in the book, including the selection of pictures and instructions in each chapter, c) making of the book framework, to make the writing of the book can be done regularly and structured. The framework starts from; title, preface, features of the book, instructions, table of contents, Chapters of the book, structure focus, glossary, reference list, and source of images, d) collection of materials, after going through the previous stage, the next step is to collect materials for making books. Materials were included everything needed in the making of books obtained from various sources, including reference books, the internet, and other sources.

\section{Develop Product Form}

\section{Syllabus}

Developing materials, then the researcher developed the Picture described with objectives, interactive and colourful picture, and activities for students. The activities consisted of vocabulary, describing and dialogues suitable for the materials. Based on the syllabus of English lesson for Elementary School, the researcher listed the topics of the pictures described as Table 2.

Table 2. Researcher listed the topics

\begin{tabular}{ll}
\hline Chapter & \multicolumn{1}{c}{ Topics } \\
\hline Lesson 1 & My family \\
Lesson 2 & Fruits and Vegetables \\
Lesson 3 & Animals \\
Lesson 4 & My shirts \\
\hline
\end{tabular}




\section{Design Product}

The descriptions of the product contents were.

\section{Cover}

The cover was presented on a blue background which was combined with white in the middle. There was a picture of a group of children talking about something against the background of a field. The selection of images agreed to the purpose of making books. There is the title of the book, the intended use of the book, the identity of the book's researcher.

\section{Acknowledgement}

The acknowledgment written contains the background of the book. Besides, the preface contained gratitude, thanks and requests for constructive criticism or suggestions with simple design but still looks interesting.

\section{Features of the book.}

This book was arranged with some topics related to the method to teach speaking. The content of the book was based on theme based for elementary school which had some instructions: 1) look and answer, 2) read aloud, 3) let us describe, 4) listen and talk.

\section{Instruction}

Instruction was parts of book that gave some instructions in using the book. The instructions were given for the teacher and student.

\section{Content}

The content covers the order of parts contained in the book accompanied by page numbers. The contents aimed to facilitate book users in using books properly and correctly.

\section{Sub Bab Page}

Each chapter had a different design in accordance with the lesson. There were 4 chapters presented. Then there were 4 different designs at the beginning of each chapter.

\section{The Lessons}

Each lesson had the same design with a display of a white background, and there was a combination of blue and yellow lines on the top and bottom. The pictures were depended on the chapter to be studied. Besides, there were chapter titles and lesson descriptions to be conveyed. The word "lesson 1" with the crown design makes it looked more interesting. Each part of the lesson consisted of a) Basic competence, b) learning objective, c) activities, d) instruction, e) look and answer, in this section, the image presented and accompanied by questions that match images. At the bottom, there were instructions for teachers and students, f) read aloud, there were vocabularies accompanied by pictures. According to each chapter to be studied. There were instructions columns for teachers and students g) let us describe, after learning the English language every word in the discussion of "read aloud" then continued by describing the picture. It was designed to be 2 columns, containing images in column 1 and their description in column 2 which was shaped like a card. It is expected that with the description of the images students were able to improve their ability to speak English, h) dialogue, it was an addition that contained questions and answers that were relevant to each chapter.

\section{Structure focus}

The structure focused presents the grammar related to the contents of the book, which had been adjusted at the level.

\section{Glossary}

This contained of the words and the meaning that liked dictionary.

\section{References}

References contained book references used in product preparation. There were two types of references; first was references of book and the second was references of picture. 


\section{Preliminary Field Testing}

\section{Expert Validation and Expert Validation of the Book}

The researcher asked suggestion to the expert. The results of the questionnaires were calculated using the formula purposed by Levin and Stephen. The obtained results then were converted into the following parameter as described in Table 3. The researcher offered five score scales in this questionnaire. It was done by. Dr. R. Chusnu Yuli Setyo, M.Pd as the expert validator of the book presented in Table 3.

Table 3. Expert Validator

\begin{tabular}{clc}
\hline No & \multicolumn{1}{c}{ Aspects Of Assessment } & Score \\
\hline 1 & Appearance of the book & 4,2 \\
2 & Content of the book & 3,5 \\
3 & Children's interest to the book & 4 \\
& Total score of point & 3,9 \\
\hline
\end{tabular}

This shows that the mean value of the book was 3.9. It was categorized in Good scale as its position in $3.1-4$. However, it still needs revision.

\section{Expert Validation of Instructional Materials Effectiveness}

This validation was about the instructional material effectiveness. It was done by Dr. Uzlifatul Masruroh Isnawati as the expert validator of instructional materials effectiveness shown in Table 4.

Table 4. Expert validator of instructional materials effectiveness

\begin{tabular}{clc}
\hline No & \multicolumn{1}{c}{ Criteria } & Score \\
\hline 1 & Statement of objectives & 4 \\
2 & Instructional content & 4 \\
3 & Level of language & 4 \\
4 & Style of presentation & 4 \\
5 & Instructional activities & 4 \\
6 & Difficulty level & 3 \\
7 & Sequence of presentation & 3 \\
8 & Practice and review & 3 \\
Total score obtained & 29 \\
Mean & 3.6 \\
\hline
\end{tabular}

This showed that the mean value of instructional materials effectiveness earned 3.6 score. Thus, the materials effectiveness was Good. Then, the researcher still considered revising the materials. The materials effectiveness also was done by Mifro Chalina, S.Pd as the expert validator can be seen in Table 5. This showed that the mean value of the instructional content appropriateness was 3.7. It was categorized in Good scale as its position in $3.1-4$. However, it still needs revision presented in Table 6 .

Table 5. The materials effectiveness also was done by Mifro Chalina, S.Pd as the expert validator

\begin{tabular}{clc}
\hline No & \multicolumn{1}{c}{ Criteria } & Score \\
\hline 1 & Statement of objectives & 4 \\
2 & Instructional content & 4 \\
3 & Level of language & 4 \\
4 & Style of presentation & 4 \\
5 & Instructional activities & 4 \\
6 & Difficulty level & 3 \\
7 & Sequence of presentation & 3 \\
8 & Practice and review & 4 \\
Total score obtained & 30 \\
Mean & 3.7 \\
\hline
\end{tabular}


Table 6. Main Product Revision

\begin{tabular}{|c|c|c|c|}
\hline No & Criteria & Aspects & Revision done \\
\hline \multirow[t]{3}{*}{1} & Validation of the book & Appearance of book & $\begin{array}{l}\text { Make the structure appearance in each chapter not } \\
\text { monotonous. }\end{array}$ \\
\hline & & Content of the book & Add the speaking practice for individual students. \\
\hline & & $\begin{array}{l}\text { Children's interest to } \\
\text { the book }\end{array}$ & It has been clear \\
\hline \multirow[t]{13}{*}{2} & $\begin{array}{l}\text { Instructional Materials } \\
\text { Effectiveness }\end{array}$ & Statement of objectives & $\begin{array}{l}\text { Give instruction, basic competence, learning objectives and } \\
\text { activities in each chapter. }\end{array}$ \\
\hline & & Instructional content & It has been clear \\
\hline & & Level of language & It has been clear \\
\hline & & Style of presentation & It has been clear \\
\hline & & Instructional activities & Make it varied. \\
\hline & & & There are four instructional in each chapter: \\
\hline & & & Look and answer, \\
\hline & & & Read aloud. \\
\hline & & & Let us describe. \\
\hline & & & Listen and talk \\
\hline & & Difficulty level & Change the language in the basic level \\
\hline & & $\begin{array}{l}\text { Sequence of } \\
\text { presentation }\end{array}$ & Make it clear \\
\hline & & Practice and review & $\begin{array}{l}\text { Give some dialogue to practice. } \\
\text { Give some questions. }\end{array}$ \\
\hline
\end{tabular}

\section{Final Product}

The developing of final product based on the suggestion given by the experts. It still had the same outline as the first draft which then was revised and delivered to the expert to be validated. For the publishing the product, the researcher planned to send the final product to the publisher to get the best result of the product distribution. It was purposed to acknowledge the product to the teachers and the learners of primary school as the instructional media to teach speaking.

\section{CONCLUSION}

This research aimed at developing "PICRIBE" or describing picture in speaking skills. To reach the objective, the researcher used R\&D as a method in conducting the research. The stages used by the researcher were adapted from (Gall et al., 1996). There were five steps which should be done. The first step was organizing research and information collection. The researcher employed three ways to collect the data. They were questionnaires, interview, and observation sheet. The second step was planning. The researcher used the result of information collection and research as the basis to plan the proposed use of the product, product users, product components, design, or research steps in a limited scope of the product. The third stage was developing product form. After planning, the researcher arranged the product to improve describing picture in speaking skills. There were four chapters in this book to teach speaking. The fourth stage was testing of the product; the researcher purposed the draft to the expert validate. This stage was done by giving questionnaires to experts (lecturers and teacher) of English. The validity included validation of the book and material validation. After getting some suggestion and appraisals from the expert, and then products that had been revised by experts were tested on students through limited scale.

The researcher went to the fifth stage, revision of the main product. The researcher refined the book according to the suggestions, comments, and the expert's additions. Thus, the researcher purposed the final product and planned continue to make the book be the books' series and the last sent the final product to the publisher. The final product of the research was compiling a book entitled "PICRIBE". The entire chapter mostly focused on the students' speaking skills. The book was for fourth-class of primary students. After the entire of the research, the researcher concluded that the research produced a book entitled "PICRIBE" which can be a handbook teacher and students to learn speaking. The book contains of describing picture. 


\section{REFERENCES}

Al-Sobhi, B. M. S., \& Preece, A. S. (2018). Teaching English speaking skills to the Arab students in the Saudi school in Kuala Lumpur: Problems and solutions. International Journal of Education and Literacy Studies, 6(1), 1-11.

Bashir, M., Azeem, M., \& Dogar, A. H. (2011). Factor effecting students' English speaking skills. British Journal of Arts and Social Sciences, 2(1), 34-50.

Brown, H. D. (2007). Principles of language learning and teaching fifth edition. White Plains, NY: Pearson Education.

Campbell, R., \& Wright, H. (1990). Deafness and immediate memory for pictures: Dissociations between "inner speech" and the "inner ear"? Journal of Experimental Child Psychology, 50(2), 259-286.

Cooper, F. L. (2007). Fun English for kids: How to teach English to very young learners. California: Creative Commons Attribution.

Fatmawati, R. (2009). Kurikulum bahasa inggris untuk sekolah dasar. Warta, 12(2), 125-135.

Gall, M. D., Borg, W. R., \& Gall, J. P. (1996). Educational research: An introduction. Longman Publishing.

Gunasekaran, A. (1999). Agile manufacturing: A framework for research and development. International Journal of Production Economics, 62(1-2), 87-105.

Hamzah, A. (2019). Metode penelitian dan pengembangan research \& development. Malang: Literasi Nusantara Abadi.

Harjuno, I. (2009). The effectiveness of using pictures to teach vocabulary about objects around school environment. Faculty of Languages and Arts. Semarang State University.

Harmer, J. (2007). The practice of English language teaching. In English: Pearson Longman. Harlow.

Inayah, A. (2019). English teaching instruction for non-English learners. English Teaching Instruction for Non-English Learners.

Indonesia, P. R. (2003). Undang-undang Republik Indonesia nomor 20 tahun 2003 tentang sistem pendidikan nasional. Departemen Pendidikan Nasional.

Karimata, M. A. (2019). Developing writing material by using Blended Learning in Vocational High Schools.

Kusumawardhani, P., \& Nurhayati, N. (2019). Students' attitudes toward using instagram the analysis of teaching writing to English Young Learners (EYL) through a movie: An ICT perspective in teaching writing. Wanastra: Jurnal Bahasa Dan Sastra, 11(1), 25-36.

Nunan, D. (1991). Language teaching methodology (Vol. 192). New York: prentice hall.

Piaget, J. (1976). Piaget's theory. In Piaget and his school (pp. 11-23). Springer.

Pratiwi, Z. F., \& Ayu, M. (2020). The use of describing picture strategy to improve secondary students 'speaking skill. Journal of English Language Teaching and Learning, 1(2), 38-43.

Ratminingsih, N. M., \& Budasi, I. G. (2018). Local culture-based picture storybooks for teaching English for young learners. SHS Web of Conferences, 42, 16.

Tarigan, D. (2006). Materi pokok pendidikan bahasa Indonesia. Jakarta: Departemen P Dan K.

Van Kraayenoord, C. E., \& Paris, S. G. (1996). Story construction from a picture book: An assessment activity for young learners. Early Childhood Research Quarterly, 11(1), 41-61. 